\title{
Chicken Selenium Status When Fed a Diet Supplemented with Se-Yeast
}

\author{
S. KURICOVÁ ${ }^{1}$, K. BOLDIŽÁROVÁ ${ }^{2}$, L. GREŠÁKOVÁ ${ }^{2}$, R. BOBČEK ${ }^{3}$, M. LEVKUT ${ }^{1}$, L. LENG ${ }^{2}$ \\ ${ }^{1}$ Institute of Pathological Anatomy, University of Veterinary Medicine, Košice \\ ${ }^{2}$ Institute of Animal Physiology, Slovak Academy of Sciences, Košice, Slovak Republic \\ ${ }^{3}$ Slovak Agricultural University, Nitra, Slovak Republic
}

Received October 31, 2002

Accepted September 22, 2003

\begin{abstract}
Kuricová S., K. Boldižárová, L. Grešáková, M. Levkut, L. Leng: Chicken Selenium Satus When Fed a Diet Supplemented with Se-Yeast. Acta Vet. Brno 2003, 72: 339-346.

This experiment was designed to investigate the effects of the feed supplementation with inorganic and organic forms of Se on the activity of blood glutathione peroxidase (GSH-Px) and the Se levels in blood and tissues in young female chickens of the laying strain Isa Brown. The first group of birds received the basic diet (BD) with Se content $0.12 \mathrm{mg} \cdot \mathrm{kg}^{-1}$ of dry matter (DM). Diets for Groups 1, 2 and 3 consisted of BD supplemented with sodium selenite $0.2 \mathrm{mg} \cdot \mathrm{kg}^{-1} \mathrm{of}$ $\mathrm{DM}$, Se-enriched yeast 0.2 and $0.7 \mathrm{mg} \cdot \mathrm{kg}^{-1}$ of DM, respectively. The experiment lasted from hatching until 7 weeks of age. The activity of blood GSH-Px was found to be dose-dependent throughout the experiment with no differences due to the form of Se administered. The selenium analysis in blood and liver samples revealed also the Se dose dependent responses but with significantly higher values recorded in chickens aged 5 weeks and older chickens and supplied with the equivalent amounts of organic Se source. Other tissue Se levels were also highest $(\mathrm{P}<$ $0.05)$ in the group with its largest intake. The values of Se content in the breast muscle were higher $(P<0.001)$ in chicks of Group 3 during entire experiment and they reached the doubled values than in the birds given selenite $\left(11.54 \pm 0.4\right.$ vs. $5.47 \pm 0.2 \mu \mathrm{mol} \cdot \mathrm{kg}^{-1}$ of DM, in 7 -weekold birds). On the other hand, no differences in this parameter were determined between the chicks fed just BD or BD supplemented with $\mathrm{Na}_{2} \mathrm{SeO}_{3}$. At the end of experiment, the intake of Se-yeast (Group 3 ) resulted in significantly $(P<0.05)$ higher Se levels in the heart, in lungs and in the gizzard than BD with selenite. No effects of the form of selenium used could be found in the spleen and kidney samples of 7-week-old chicks. The results demonstrate the evident advantage of supplementation of poultry feed with the selenium-enriched yeast due to more effective Se utilization and formation of mobile body deposits of this microelement than in the case of supplementation with selenite.

Poultry, selenium, bioavailability, glutathione peroxidase, striated muscle, liver
\end{abstract}

Selenium is well known to be an essential trace element with the vital function in humans and animals. In nature, it can be found in the elemental form as well as incorporated into both inorganic and organic compounds. Animals receive Se mainly by a plant feed in a form of selenoamino acid - selenomethionine (Schrauzer 2000a). Selenium in a form of another amino acid - selenocysteine is the central structural component of specific selenoenzymes like glutathione peroxidases, iodothyronine deiodinases, thioredoxin reductases, selenophosphate synthetase and many others. Up to date about 30 selenoproteins were described but the precise function of most of them is not known yet. The best understood selenoenzyme appears to be cytosolic glutathione peroxidase (cGSH-Px, EC 1.11.1.9), which acts as the antioxidant be a removing of reactive oxygen species (Behne and Kyriakopoulos 2001).

Adequate intake of selenium supports the development of immunocompetent functions. It is well known that its deficiency results in the insufficient cell and humoral immune response of humans and animals (R a y man 2000). On the other hand, the increased supply to humans showed some anticancerogenic effects (Schrauzer 2000b).

Address for correspondence:

Addross for correspondence:

Institute of Animal Physiology

Šoltésovej 4, 04001 Košice, Slovak Republic
Phone: +421556332048

Fax: + 42155748784

http://www.vfu.cz/acta-vet/actavet.htm 
The consequences of deficient Se intake in farm animals such as nutritional myodystrophy (white muscle disease), exudative diathesis, disorders of liver and pancreatic function and many other syndromes are well described. The associated problems are impaired performance and production, problems with reproduction and considerable economic losses due to animal deaths. A different situation might be induced by a marginal deficiency of Se and/or by the using of solely inorganic selenium sources to supplement the feedstuffs. In such case a delayed development of immune system of young chicks may occur along with impaired feathering and subsequent energy losses, increased number of dead birds, reduced egg production, and increased embryonic mortality (Finch and Turner 1996; Surai 2000; Edens et al. 2002).

In most European countries the natural background of selenium in the components of animal feeds, formed mainly by selenoamino acids Se-methionine and Se-cysteine of proteins reaches the level of only $0.03-0.12 \mathrm{mg} \cdot \mathrm{kg}^{-1}$ of DM with a tendency to be at lower margin of this range. Intake of such a feed can result in the serious Se deficiency with relevant health problems especially in high productive animals (Pavlat a et al. 2000, 2001c, 2002). That is why the feedstuffs are widely supplemented with various selenium sources in order to reach the final Se levels from 0.3 to $0.5 \mathrm{mg} \cdot \mathrm{kg}^{-1}$ of DM. Recently the trends to prefer the organic forms of the selenium supplements as high Se-yeast (Pavlata et al. 2001ab) or seleninotriglycerides (Zagrodzki et al. 2000) to the feeds of farm animals instead of inorganic Se compounds appeared. Despite of generally accepted opinion on the advantages of the organic selenium arising from Se-yeast, the inorganic formulas of this trace element such as sodium selenite are still widely used in Central European countries.

The objectives of this work were to compare the effects of feed supplementation with sodium selenite and with Se-yeast on incorporation of Se into the tissues, and on the activity of selenoenzyme glutathione peroxidase (GSH-Px) in blood of chickens from the first day of life until the age of 7 weeks.

\section{Materials and Methods}

Two hundred female chickens of the laying strain Isa Brown were obtained on the day of hatching from LP-Párovské Háje hatchery (Slovak Republic). They were divided into 4 groups of 50 birds each, and kept in large pens with wood shavings. From day 1 of life until the age of seven weeks the chickens were fed diets differring in total content of selenium or in the form of Se supplemented only. Group 1 was given the basic diet (BD) with Se content $0.12 \mathrm{mg} \cdot \mathrm{kg}-1$ of dry matter (DM) occurring naturally in the dietary components. The diet Group 2 was the same BD plus Se supplement $0.2 \mathrm{mg} \cdot \mathrm{kg}^{-1}$ of DM in the form of $\mathrm{Na}_{2} \mathrm{SeO}_{3}$ resulting in the final selenium level 0.32 $\mathrm{mg} \cdot \mathrm{kg}^{-1}$ of DM. Group 3 received a BD supplemented with $0.2 \mathrm{mg}$ of $\mathrm{Se}$ in the form of selenium yeast extract (Sel-Plex, Alltech, USA) yielding the same final Se level $0.32 \mathrm{mg} \cdot \mathrm{kg}^{-1}$ of DM as in the diet for Group 2 . The diet for Group 4 consisted of BD enriched with selenium $\left(0.7 \mathrm{mg} \cdot \mathrm{kg}^{-1}\right.$ of DM) in the form of the same Se-yeast extract providing a total concentration of $0.82 \mathrm{mg} \cdot \mathrm{kg}^{-1} \mathrm{DM}$.

The diets for Groups 1, 2 and 3 were also fortified with adequate amounts of the yeast extract without Se (NUPRO, Alltech, USA) to obtain the same final levels of the yeast extract as in the 4 th diet $(63.7 \mathrm{~g}$ per $100 \mathrm{~kg}$ of feed). Mineral and vitamin premix for mixing into diets was supplied by Biotika a.s. (Slovak Republic). The final contents of vitamin $\mathrm{E}, \mathrm{Cu}$ and $\mathrm{Zn}$ were $159,13.58$ and $113.07 \mathrm{mg} \cdot \mathrm{kg}^{-1}$ of DM in feed for each group, respectively. The composition of BD is presented in Table 1.

Table 1

The composition of the basic diet for chickens

\begin{tabular}{|lc|ll|}
\hline Component & $\%$ & Component & $\%$ \\
\hline Corn, ground, 9\% of crude protein (CP) & 53.0 & Dicalcium phosphate (20\% of P) & 0.3 \\
Solvent extracted soybean meal & & Salt & 0.25 \\
(3.5\% of crude fibre, 48\% of CP) & 23.0 & Meat and bone meal with a middle & 5.0 \\
Fish meal (65\% of CP) & 4.0 & contents of fat, 48\% of CP & 2.0 \\
Wheat, ground (11\% of CP) & 11.45 & Pulverised fat, BERGAFAT HPL 106 & \\
Premix BR 1 Forte & 1.0 & & \\
\hline
\end{tabular}

a - supplied per $1 \mathrm{~kg}$ of diet: vitamin A, $12500 \mathrm{IU}$; vitamin D3, $3500 \mathrm{ICU}$; vitamin E, $150 \mathrm{mg}$; vitamin $\mathrm{K}_{3}, 4 \mathrm{mg}$; thiamine, 3 $\mathrm{mg}$; riboflavin, $9 \mathrm{mg}$; pyridoxine, $6 \mathrm{mg}$; cyanocobalamin, $40 \mu \mathrm{g}$; niacin, $60 \mathrm{mg}$; pantothenic acid, $15 \mathrm{mg}$; betain, $277 \mathrm{mg}$; biotin, $0.2 \mathrm{mg}$; folic acid, $2 \mathrm{mg}$; L-lysine, $1.2 \mathrm{~g}$; DL-methionine, $1 \mathrm{~g} ; \mathrm{Zn}, 80 \mathrm{mg} ; \mathrm{I}, 1 \mathrm{mg} ; \mathrm{Co}, 0.4 \mathrm{mg}$; Mn, $100 \mathrm{mg} ; \mathrm{Cu}, 8 \mathrm{mg} ; \mathrm{Fe}, 80 \mathrm{mg}$ 
Chickens were first reared at a lighting regimen of 23L:1D which was adjusted to $15 \mathrm{~L}: 9 \mathrm{D}$ after three weeks of their age. The initial room temperature $32-33{ }^{\circ} \mathrm{C}$ was reduced every week by $3{ }^{\circ} \mathrm{C}$ to a final temperature of $23{ }^{\circ} \mathrm{C}$. All animals had free access to water and feed. Experiment was carried out according to established standards for use of animal. The protocol was approved by local ethical and scientific authorities.

Six chickens of each group were anaesthetised with an intraperitoneal injection of Pentobarbital (Spofa, Czech Republic) at a dose of $60 \mathrm{mg} \cdot \mathrm{kg}^{-1}$ body weight at weekly intervals. Blood was collected by intracardial punction and placed in heparinized tubes. Thereafter the anaesthetised chickens were slaughtered for collection of tissue samples from liver, heart, breast muscle, spleen, lungs, gizzard and kidneys. Samples that were not analysed immediately were frozen at $-24{ }^{\circ} \mathrm{C}$.

The activity of blood GSH-Px was determined by standard set RANSEL from Randox, UK (Paglia and Valentine 1967). Haemoglobin was analysed by a set of Randox, UK. The levels of selenium in feed, excrements, blood and tissues were analysed in triplicates by the fluorimetric method of Rodriguez et al. (1994). The concentration of Se in blood was measured in chickens aged 3, 4, 5, 6 and 7 weeks only. The standard procedure of the tissue and feeds drying in the oven at $105^{\circ} \mathrm{C}$ was used to determine the dry matter (DM) contents.

Statistical analysis of the results was done by one-way analysis of variance with the post hoc Tukey and Dunett post-tests where appropriate. The results are presented as means SEM.

\section{Results}

Selenium analysis in blood samples from the entire experiment showed that except for week 4 , the Se concentration was significantly higher in both groups of birds receiving organic Se than in the chickens kept on basic diet or diet supplemented with selenite (upper part of Fig. 1).

The activity of blood GSH-Px was found to be significantly highest in chicken of $4^{\text {th }}$ group supplied with the largest intake of organic Se (bottom part of Fig. 1). During the entire experiment we did not find any statistically significant differences in this variable between the Group 2 (supplied with $\mathrm{Na}_{2} \mathrm{SeO}_{3}$ ) and Group 3 with the equivalent amount of $\mathrm{Se}$ in $\mathrm{Se}$ yeast. There was evidently a sharp fall of the GSH-Px activity in birds on the diet with basic Se content (Group 1) within the first two weeks of life when the chickens are most sensitive to various stress factors. Interestingly, activity of this selenoenzyme in blood of Group 1 chickens did not reach the basic levels found on the day of hatching even at 7 weeks of age.

Concentrations of Se in the liver tissue of chickens fed diets with various amounts and forms of this microelement are depicted on the upper part of Fig. 2. The measured values followed the pattern similar to blood with the highest Se levels reached in animals fed a diet with its largest supply. Significant differences between the effects of inorganic and organic selenium appeared (Group 2 vs. 3) after six weeks.

The most striking effect of Se-yeast was determined in breast muscle (bottom part of Fig. 2). The Se content in this tissue was found to be highly significantly higher $(P<0.001)$ during the entire experiment in birds of Group 3 on Se-yeast than in breast musculature of those given the equivalent amount of sodium selenite. The highest $\mathrm{Se}$ concentration recorded in muscle tissue of Group 4 illustrated the dose-dependent effect of organic Se supplementation.

The values of selenium contents in tissues of further organs at the end of experiment ( 7 weeks) are presented in Table 2. The lowest values were recorded in the group maintained on diet with basic content of Se and the highest ones were found in Group 4 with largest selenium intake. The significantly higher Se contents appeared in heart, lungs and gizzard of Group 3 supplied with Se yeast compared to Group 2 with addition of $\mathrm{Na}_{2} \mathrm{SeO}_{3}$. Again, the highest values were determined in Group 4 fed a diet supplied with the largest amount of Se-yeast.

\section{Discussion}

Results of this experiment showed that the activity of blood GSH-Px in young chickens was dependent on the amount of selenium supplied to feed. No significant effects of the form of selenium source used could be determined. The rational explanation is based on the findings that 

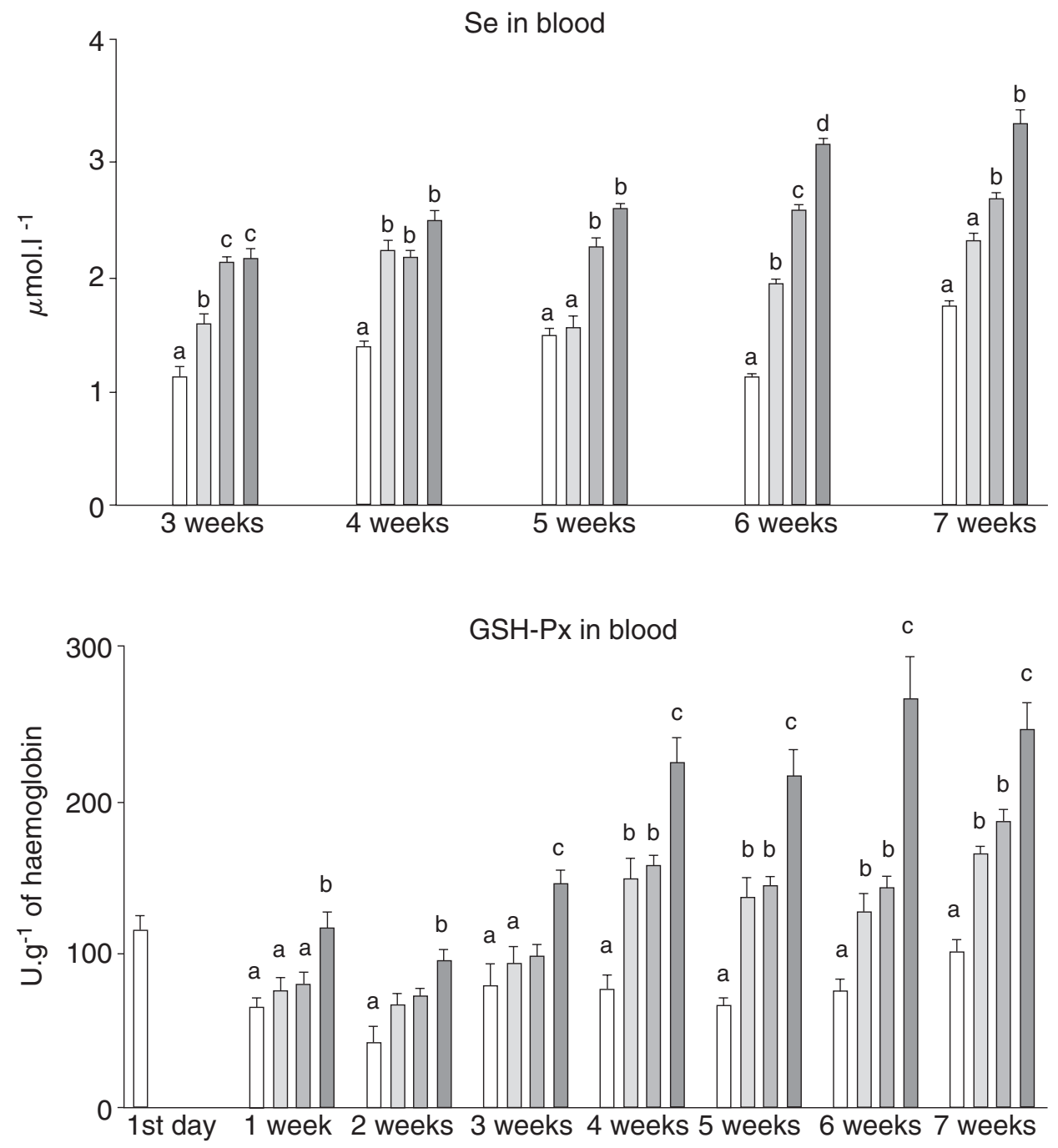

$$
\begin{aligned}
& \square \text { Basic diet (BD), Se content } 0.12 \mathrm{mg} \cdot \mathrm{kg}^{-1} \\
& \square \text { BD + organic Se } 0.2 \mathrm{mg} \cdot \mathrm{kg}^{-1} \\
& \square \text { BD + inorganic Se } 0.2 \mathrm{mg} \cdot \mathrm{kg}^{-1} \\
& \hline \text { BD + organic Se } 0.7 \mathrm{mg} \cdot \mathrm{kg}^{-1}
\end{aligned}
$$

Fig. 1. The effects of supplementing the feed with inorganic $\left(\mathrm{Na}_{2} \mathrm{SeO}_{3}\right)$ and organic (Se-yeast) form of selenium on the blood Se concentrations in chickens from $3^{\text {rd }}$ week of their life and on the development of activity of blood glutathione peroxidase (GSH-Px) from the day of hatching till 7 weeks of their age. Values are means SEM. Distinct letters above columns $=$ significant differences $(P<0.05) . \mathrm{n}=6$ for each group and week.

all Se-compounds must be split to $\mathrm{H}_{2} \mathrm{Se}$ before the selenocysteine is synthetized actually de novo for an incorporation into the active centre of selenoenzyme (Schrauzer 2000a). It is of interest that the activity of blood GSH-Px did not reach a plateau even at the high content of Se in the feed 
Se content in liver
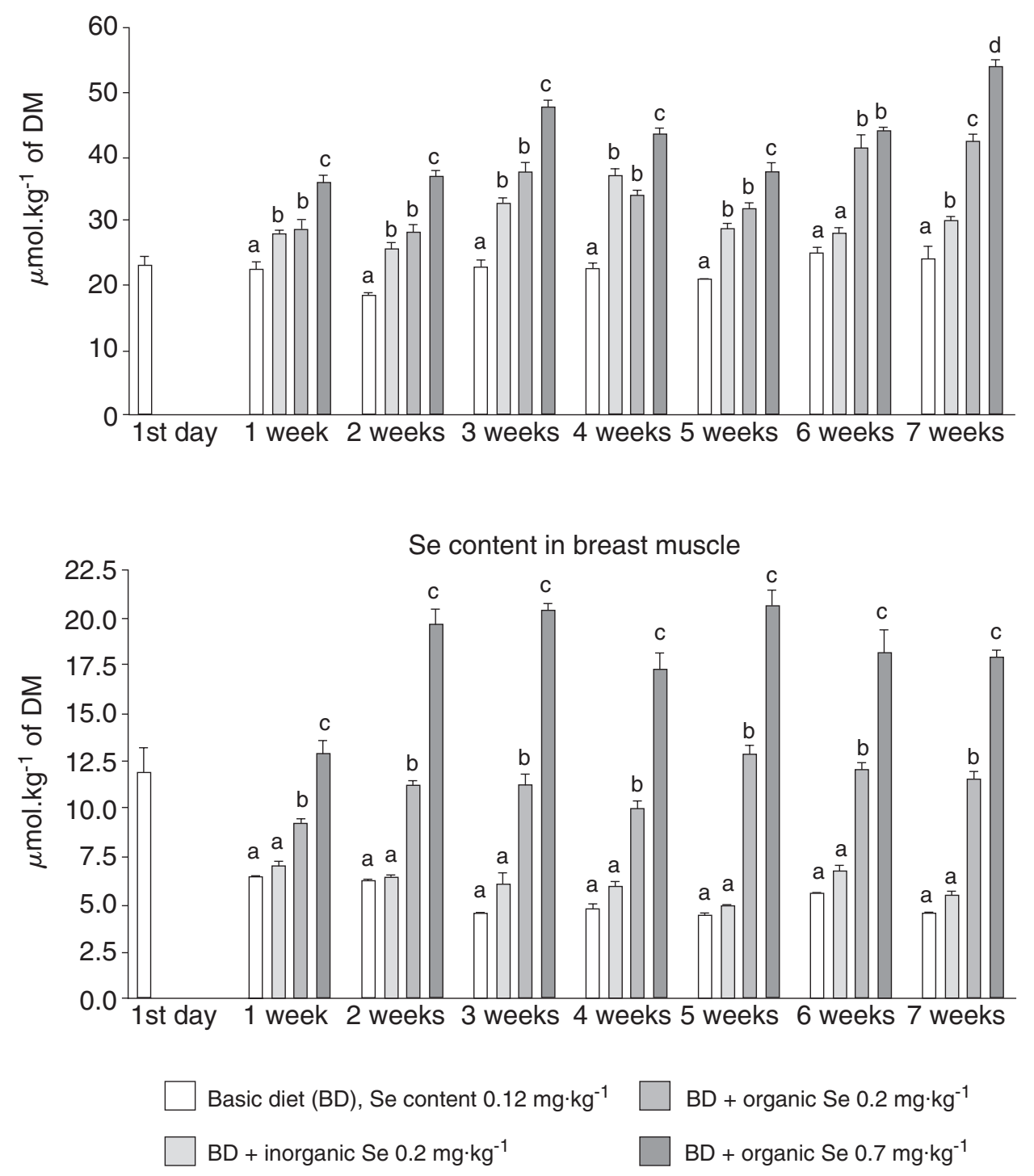

Fig. 2. The effects of supplementing the feed with inorganic $\left(\mathrm{Na}_{2} \mathrm{SeO}_{3}\right)$ and organic (Se-yeast) form of selenium on the Se contents in liver and breast muscle tissue of chickens from the day of hatching till 7 weeks of their age. Values are means SEM. Distinct letters above columns $=$ significant differences $(P<0.05$ for liver and $\mathrm{P}<0.001$ for breast muscle). $\mathrm{n}=6$ for each group and week.

of Group $4\left(0.82 \mathrm{mg} \cdot \mathrm{kg}^{-1}\right)$. In contrary, we have recently found that the increase in selenium intake in analogue experiment did not result in any increase of the activity cGSH-Px in chicken liver tissue (Holovská et al. 2003), and yet the intake of diet with just basic content of Se 
Table 2

The Se contents in tissues (?mol $\cdot \mathrm{kg}^{-1}$ of DM) of seven weeks old chickens fed diets supplemented with inorganic $\left(\mathrm{Na}_{2} \mathrm{SeO}_{3}\right)$ and organic (Se-yeast) form of selenium. Values are means SEM.

\begin{tabular}{|c|c|c|c|c|}
\hline Tissue & $\begin{array}{l}\text { Basic diet (BD), } \\
\text { Se } 0.12 \mathrm{mg} \cdot \mathrm{kg}^{-1} \\
\mathrm{n}=6\end{array}$ & $\begin{array}{l}\mathrm{BD}+\text { inorganic } \mathrm{Se} \\
0.2 \mathrm{mg} \cdot \mathrm{kg}^{-1} \\
\mathrm{n}=6\end{array}$ & $\begin{array}{l}\mathrm{BD}+\text { organic } \mathrm{Se} \\
0.2 \mathrm{mg} \cdot \mathrm{kg}^{-1} \\
\mathrm{n}=6\end{array}$ & $\begin{array}{l}\mathrm{BD}+\text { organic Se } \\
0.7 \mathrm{mg} \cdot \mathrm{kg}^{-1} \\
\mathrm{n}=6\end{array}$ \\
\hline Heart & $16.75 \pm 0.51^{\mathrm{a}}$ & $18.59 \pm 0.63^{\mathrm{a}}$ & $26.80 \pm 0.38^{b}$ & $36.28 \pm 0.79^{c}$ \\
\hline Lungs & $23.60 \pm 0.57^{\mathrm{a}}$ & $25.30 \pm 0.92^{\mathrm{a}}$ & $32.45 \pm 0.88^{b}$ & $39.12 \pm 1.09^{c}$ \\
\hline Gizzard & $24.48 \pm 0.34^{\mathrm{a}}$ & $26.47 \pm 0,51^{\mathrm{a}}$ & $30.02 \pm 0,66^{b}$ & $41.26 \pm 0,85^{\mathrm{c}}$ \\
\hline Spleen & $28.69 \pm 0.55^{\mathrm{a}}$ & $30.64 \pm 0.69^{a b}$ & $33.57 \pm 0.61^{b c}$ & $43.55 \pm 1.16^{\mathrm{d}}$ \\
\hline Kidney & $39.01 \pm 1.25^{\mathrm{a}}$ & $45.02 \pm 1.11^{\mathrm{b}}$ & $49.02 \pm 1.47^{\mathrm{bc}}$ & $61.75 \pm 1,26^{\mathrm{d}}$ \\
\hline
\end{tabular}

Distinct letters in superscript $=$ significant differences $(P<0.05)$

saturated its activity. It seems that activity of different types of GSH-Px in various tissues might be saturated at diverse levels of Se entry. Up to date there were 5 types of glutathione peroxidases described - cytosolic or classical cGSH-Px, gastrointestinal GI-GSH-Px, plasma pGSH-Px, phospholipid peroxide PH-GSH-Px and sperm nuclei snGSH-Px (Behne and Kyriakopoulos 2001). The main function of these peroxidases is removal and/or detoxication of hydrogen peroxides and lipid hydroperoxides to less harmful alcohols (Ursiny et al. 1997; Mates and Sanchez 1999). The larger effect on blood GSH-Px activity of Se-yeast supplementation to feed than that of sodium selenite has been determined in other animal species but it seemed to be just a consequence of evident Se-deficiency (Yoshida et al. 1999).

Our results unequivocally confirmed the more efficient utilization of the organic form of selenium in chickens as reflected by its higher levels in most of tissues and mainly in the muscles than with $\mathrm{Na}_{2} \mathrm{SeO}_{3}$. The most striking finding in Group 3 given Se-yeast was the double Se contents in muscle during entire experiment comparing to birds of Group 2 with an adequate intake of sodium selenite. Another noteworthy result of the Se analysis in muscle is that during whole experiment ( 7 weeks) we did not find significant differences in any of weekly collected samples among chickens given a diet with the basic selenium content or diet with the additional selenite supply. Moreover, the muscle Se level in 7-week-old birds supplied with inorganic Se fell highly significantly to a value less than half of that on day of hatching (from $11.8 \pm 1.3$ to $5.5 \pm 0.2 \mu \mathrm{mol} \cdot \mathrm{kg}^{-1}$ of DM, $\left.P<0.001\right)$. The larger body retention of selenium from Se-yeast than from selenite was recently demonstrated also in our balance experiments in chicks (Grešáková et al. 2002).

The portion of selenomethionine absorbed from the digestive tract that is not used immediately for synthesis of specialized selenoproteins is incorporated non-specifically into the structural proteins of muscle, gizzard, heart and other organs. Selenomethionine substitutes here the common amino acid methionine which contains in its molecule sulphur instead of selenium (Schrauzer 2000a). In this way the muscle tissue becomes the most significant deposit of selenium in the form of selenomethionine when using organic Se for nutrition of animals. The reason is that the striated muscle mass represents about $52-56 \%$ of the body weight of chicken. The intensive uptake of selenomethionine by muscle proteins is very important also from the point of view of increased transport of Se from mother hens to eggs and embryos, for the subsequent development of chicken immunocompetence and overall health state of birds (Surai 2000). The wide supplying of organic Se in a form of selenomethionine to chicken feedstuffs should bring the benefits also to the human 
population via the food chain. The marginal to middle deficient intake of selenium by humans has been established in Central European countries (Kvičala 1996; Kadrábová et al. 1998).

On the other hand, selenite - not engaged in synthesis of specialized selenoproteins - does not have a metabolic pathway for a non-specific incorporation of its Se into the proteins of muscle, heart, gizzard and others natural body deposits of selenium in chickens. Another disadvantage of selenite appears to be its considerable prooxidative features (S pallholz 1997). This finding is especially alarming in the light of recent results of Kobayashi et al. (2001). These researchers showed that $\mathrm{Se}$ bound in the form of selenide $\left(\mathrm{H}_{2} \mathrm{Se}\right)$ to albumin is susceptible to oxidation, yielding selenite $\left(\mathrm{SeO}_{3}{ }^{-2}\right)$ in vitro, and, moreover, they suggested that this process might occur also in vivo. It should be understood that selenite is a key product of the metabolism of sodium selenite in the body before selenium is incorporated into the specific selenoproteins. Newly formed selenite continually produces the reactive oxygen species in the body during the very rapid diffusive recycling between plasma and red blood cells. After the multiple recycling of inorganic Se via selenide to selenite transformation pathway and its methylation the surplus of inorganic selenium is rapidly excreted by urine (Boldižárová et al. 2001).

This can be an explanation why the occasional overdosing with selenomethionine does not result in such severe toxic consequences in animals as is the case with inorganic $\mathrm{Se}$ (S urai 2002). Our recent work demonstrated that 4-week-old chickens did not respond to feeding a marginal supply of organic Se (plus $0.7 \mathrm{mg} \cdot \mathrm{kg}^{-1} \mathrm{Se}$ ) by a higher production of thiobarbituric acid reactive substances (TBARS) in liver than the birds on basic diet with $0.12 \mathrm{mg} \cdot \mathrm{kg}^{-1}$ of Se (Holovská et al. 2003). Thereafter the harmful prooxidative effects of selenide to selenite recycling are almost eliminated with using of organic Se in feedstuffs.

In conclusion, the results of this experiment demonstrate the unequivocal benefits of supplementation of poultry feed with Se-yeast resulting in a considerably more effective Se utilization and formation of mobile body deposits of this microelement than in the case of addition of selenite.

\section{Odpoved' selénového statusu kurčiat na dotáciu krmiva selenizovanými kvasinkami}

V pokuse sme sledovali vplyv prídavku anorganickej a organickej formy selénu do krmiva na aktivitu krvnej glutatión peroxidázy (GSH-Px) a na obsah Se v krvi a tkanivách u kurčiat -sliepočiek nosivého plemena Isa Brown. Prvá skupina vtákov dostávala základnú diétu (BD) s obsahom selénu $0,12 \mathrm{mgŠkg}^{-1}$ sušiny. Diéty pre ostatné skupiny pozostávali z BD obohatenej selénom vo forme seleničitanu sódneho v množstve $0,2 \mathrm{mgŠkg}^{-1}$ sušiny (2. skupina), z BD obohatenej Se vo forme Se-kvasiniek v množstve $0,2 \mathrm{mgŠkg}^{-1}$ sušiny (3. skupina) a z BD obohatenej selénom tiež Se-kvasinkami, ale v množstve až $0,7 \mathrm{mgS̆kg}^{-1}$ sušiny (4. skupina). Kurčatá prijímali tieto diéty od 1. dňa po vyliahnutí až do 7. týždňa ich veku. Zistili sme, že aktivita krvnej GSH-Px bola počas celého pokusu závislá na dávke selénu bez rozdielnych účinkov jeho použitej formy. Obsah Se v krvi a pečeni bol tiež závislý na jeho dávke, ale signifikantne zvýšené hodnoty oproti 2. skupine boli zistené od 5. týždňa veku u kurčiat prijímajúcich organickú formu selénu. Koncentrácie selénu v ostatných tkanivách boli tiež signifikantne najvyššie v skupine s jeho najväčším príjmom. Obsah selénu v prsnej svalovine bol počas celého pokusu vysoko signifikantne väčší $(P<0,001)$ u kurčiat v 3. skupine a dosahoval až dvojnásobné hodnoty oproti vtákom, ktoré dostávali seleničitan sódny (11,54 $\pm 0,4$ vs. 5,47 $\pm 0,2 \mu \mathrm{molŠkg}^{-1}$ sušiny v 7. týždni veku vtákov). Naproti tomu žiadne rozdiely $\mathrm{v}$ tomto parametri sme nezistili medzi kurčatami kŕmenými základnou diétou a diétou obohatenou o $\mathrm{Na}_{2} \mathrm{SeO}_{3}$. Na konci pokusu mali kurčatá 3. skupiny s príjmom Sekvasiniek signifikantne vyššie hladiny Se aj v srdci, plúcach a svalnatom žalúdku, než vtáky dostávajúce diétu dotovanú ekvivalentným množstvom seleničitanu. V slezine a obličkách 
sme nezistili žiadny vplyv použitej formy selénu na jeho obsah v týchto orgánoch u 7týždňových kurčiat. Výsledky poukazujú na jednoznačnú výhodu dotácie krmiva hydiny kvasničnými preparátmi Se kvôli jeho lepšej utilizácii a tvorbe mobilných telových depozitov tohto mikroelementu, než pri pridávaní seleničitanu sódneho.

\section{References}

BEHNE, D, KYRIAKOPOULOS, A 2001: Mammalian selenium-containing proteins. Ann Rev Nutr 21: $453-473$ BOLDIŽÁROVÁ, K, FAIX, Š, LENG, L 2001: The effects of intravenous infusion of sodium selenite on the renal excretion of selenium in sheep. Proceedings of 19th Days of Animal Physiology, Košice, p. 64

EDENS, FW 2002: Practical applications for selenomethionine: broiler breeder reproduction. In: TP Lyons and KA Jacques (Eds): Nutritional Biotechnology in the Feed and Food Industries. Proceedings of Alltech's $18^{\text {th }}$ Annual Symposium. Nottingham University Press. pp. 29-42

FINCH, JM, TURNER, RJ 1996: Effects of selenium and vitamin E on the immune responses of domestic animals. Res Vet Sci 60: 97-106

GREŠÁKOVÁ, L, BOLDIŽÁROVÁ, K, FAIX, Š, LENG, L 2002: The effects of different contents and form of selenium in feed on its balance in chickens. Proceedings of 20th Days of Animal Physiology, Třešt, p. 12

HOLOVSKÁ Jr K, HOLOVSKÁ K, BOLDIŽÁROVÁ, K, ČEKONOVÁ, S, LENÁRTOVÂ, V, LEVKUT, M, JAVORSKÝ P, LENG, L' 2003: The antioxidant enzyme activities in the liver tissue of chickens fed diets supplemented with various forms and amounts of selenium. J Anim Feed Sci 12: 143-152

KADRÁBOVÁ, J, MAĎARIC, A, GINTER, E 1998: Determination of the daily selenium in Slovakia. Biol Trace Elem Res 61: 277-286

KOBAYASHI, Y, OGRA, Y, SUZUKI, KT 2001: Speciation and metabolism of selenium injected with ${ }^{82}$ Seenriched selenite and selenate in rats. J Chromatogr B 760: 73-81

KVIČALA, J 1996: Status and selenium intake as related to the thyroid gland in the population of the Znojmo. Vnitř Lék 42: 738-742

MATES, JM, SANCHEZ, FJ 1999: Antioxidant enzymes and their implications in pathophysiologic processes. Front Biosci 4: D339-D345

PAGLIA, DE, VALENTINE, WN 1967: Studies on quantitative and qualitative characterization of erythrocyte glutathion peroxidase. J Lab Med 70: 158-169

PAVLATA, L, PECHOVÁ, A, ILLEK, J 2000: Direct and indirect assessment of selenium status in cattle a comparison. Acta Vet Brno 69: 281-287

PAVLATA, L, ILLEK, J, PECHOVÁ, A 2001a: Blood and tissue selenium concentrations in calves treated with inorganic or organic selenium compounds - a comparison. Acta Vet Brno 70: 19-26

PAVLATA, L, PECHOVÁ, A, BEČVÁŘ, O, ILLEK, J 2001b: Selenium status in cattle at slaughter: analyses of blood, skeletal muscle and liver. Acta Vet Brno 70: 277-284

PAVLATA, L, PECHOVÁ, A, ILLEK, J 2001c: Muscular dystrophy in dairy cows following a change in housing technology. Acta Vet Brno 70: 269-275

PAVLATA, L, ILLEK, J, PECHOVÁ, A, MATĚJÍČEK, M 2002: Selenium status of cattle in the Czech Republic. Acta Vet Brno 71: 3-8

RAYMAN, MG 2000: The importance of selenium to human health. Lancet 356: 233-241

RODRIGUEZ, EM, SANZ, MT, ROMERO, DC 1994: Critical study of fluorometric determination of selenium in urine. Talanta 41: 2025-2031

Schrauzer, NG 2000a: Selenomethionine: A review of its nutritional significance, metabolism and toxicity. J Nutr 130: $1653-1656$

SCHRAUZER, NG 2000b: Anticarcinogenic effects of selenium. Cell Molecul Life Sci 57: 1864-1873

SPALLHOLZ, JE 1997: Free radical generation by selenium compounds and their prooxidant toxicity. Biomed Environ Sci 10: 260-270

SURAI, PF 2000: Effect of selenium and vitamin E content of the maternal diet on the antioxidant system of the yolk and the developing chick. Br Poultry Sci 41: 235-243

SURAI, PF 2002: Selenium in poultry nutrition - 1. Antioxidant properties, defficiency and toxicity. World Poultry Sci J 58: 333-347

URSINY, F, MAIORINO, M, ROVERI, A 1997: Phospolipid hydroperoxide glutathione peroxidase (PHGPx): more than an antioxidative enzyme. Biomed Environ Sci 10: 327-332

YOSHIDA, M, FUKUNAGA, K, TSUCHITA, H, YASUMOTO, K 1999: An evaluation of the bioavailability of selenium in high-selenium yeast. J Nutr Sci Vitaminol 45: 119-128

ZAGRODZKI, P, BIK, D, FITAK, BA, SUCHOCKI, P, NIEMCZUK, K 2000: Selenoenzymes in animal tissues after supplementation with selol. Bull Vet Inst Pulawy 44: 215-220 